\title{
Integrated Geophysical and Geochemical Methods for Environmental Assessment of Municipal Dumpsite System
}

\author{
Elijah Adebowale Ayolabi ${ }^{1}$, Adetayo Femi Folorunso ${ }^{1,2 *}$, Olusola Titilope Kayode ${ }^{1}$ \\ ${ }^{1}$ Department of Geosciences, University of Lagos, Lagos, Nigeria \\ ${ }^{2}$ College of Marine Geosciences, Ocean University of China, Qingdao, China \\ Email: eojelabi@yahoo.com, eayolabi@unilag.edu.ng,"detayof@yahoo.com
}

Received April 18, 2013; revised May 21, 2013; accepted June 29, 2013

Copyright (C) 2013 Elijah Adebowale Ayolabi et al. This is an open access article distributed under the Creative Commons Attribution License, which permits unrestricted use, distribution, and reproduction in any medium, provided the original work is properly cited.

\begin{abstract}
Leachate originating from open refuse dumpsite systems can be delineated through an integration of qualitative and quantitative methods. This study was designed to examine extent of leachate and pollution from one of the numerous open refuse dumpsites in Lagos metropolis. Qualitative assessment was determined using electrical resistivity tomography (ERT), vertical electrical sounding (VES) and induced polarization geophysical methods. Both ERT and VES methods revealed persistent low resistivity $(1-20 \Omega \mathrm{m})$ of leachate to the depth above $35 \mathrm{~m}$. The two methods were projected to produce 3-D view of the site which shows a NW-SE flow pattern of the leachate and possibly, the groundwater. IP values observed over the polluted zone was $-2.9-8 \mathrm{~ms}$, indicating a sandy layer. Quantitative assessment was achieved by analysis of geochemical substances in the water samples taken from wells and boreholes in the precinct of the dumpsite. Here, we examine the macroelements, salts (sulphates, nitrates and chlorides), heavy metals, radioactive metals contents and physical parameters of the water samples. The analyses reveal the presence of these substances in the water and their strong correlations justified the provenance as the same. As part of the quantitative evaluation, physical parameters ( $\mathrm{pH}$, TDS, DO, salinity, total hardness, turbidity, electrical conductivity EC and temperature) of the water samples were also determined. The samples $\mathrm{pH}$ plotted in the acidic domain unsuitable for human consumption. Leachate flow direction was generated from the decreasing concentration of measured parameters (geochemical elements and physicals properties) in NW-SE direction which agrees with similar flow pattern deduced from ERT results.
\end{abstract}

Keywords: Dumpsite; Leachate; Electrical Resistivity; Hydrochemical Analysis; Pollution Depth; Heavy Metals; Contaminant Plume

\section{Introduction}

Waste disposal dumps are common phenomena especially in industrial and highly populated cities where dumps are generated in tons on a daily basis and thus becomes a more important and efficient way of maintaining a clean environment in urban settings. In developing countries unregulated landfills are commonly located adjacent to large cities, releasing harmful contaminants into a leachate and thereby polluting underlying aquifers [1-6]. Similar groundwater contamination occurs in well waters due to leachate from household septic tanks [7] and from settlement around dumps [8-10].

Municipal solid waste landfills/dumpsites have been identified as major environmental problem when located at high proximity to inhabited areas [11]. The challenges

\footnotetext{
"Corresponding author.
}

in solid waste dumping, handling, and management, all pose great threats to the environmental wholesomeness [12]. In most cases, dumpsites were originally located far from urban areas, but increasing expansion due to everincreasing population and urbanization have resulted in development of land adjacent to dumps as either public buildings or residential houses. Humans are therefore exposed to a range of environmental hazards but particularly percolation of polluted leachate into the shallow aquifers which is the main source of drinking water in developing countries. In most cases in developing countries, disposal sites are not properly planned. Thus, periodical environmental auditing exercises become an inevitable task to ascertain the conditions of waste site with view to gain the knowledge of possible interaction between its dumps and the environment.

Over the years, geochemical approaches have gained 
tremendous popularity in dumpsite leachate delineation [13-15]. The environmental challenges of waste dumps include:

- contamination of groundwater by pollutants generated by the dumps;

- migration of the pollutants away from the site via groundwater, surface water, or air routes;

- a combination of these, fire and explosion at the site, and direct contact with hazardous substances [6].

Each year about two million people die as a result of poor sanitation and contaminated water, ninety percents $(90 \%)$ of the victims are children [16]. These hazardous effects emanate from the presence of toxic elements of environmental concern in the waste; elements such like $\mathrm{Pb}, \mathrm{Cd}, \mathrm{As}$ and $\mathrm{Cr}$. Many of these metals have been found to act as biological poisons even at low concentration (parts of per billion - ppb) levels [17]. [18] also observed that the elements are toxic in the form of cations and when bonded to short chains of carbon atoms may not be toxic as free elements. Even most celebrated metals with important commercial uses are also not left out and hence undesirable for indiscriminate release into the environment [19].

This research work aims to showcase the effectiveness of integrating non-invasive geophysical methods with widely employed geochemical approach in environmental assessment of waste disposal site [9]. While the later is a quantitative phenomenon, the former elaborately displays qualitative conditions of the site. Both can map the contaminant plume and groundwater flow direction. The geophysical methods we introduced are electrical resistivity tomography ERT, vertical electrical sounding VES and induced polarization IP methods.

Electrical Resistivity Tomography (ERT) is a technique for imaging the subsurface electrical structure using electrical currents. From a series of electrodes, low frequency electrical current is injected into the subsurface, and the resulting potential distribution is measured. Early development of ERT in geophysics was confined to imaging rock core samples in the laboratory [20], but prototype data-collection hardware and research-grade inverse codes suitable for field scale applications soon followed [21]. The method has been developed to detect leaks from large storage tanks [21], monitor underground air sparging [22] and mapping movement of contaminant plumes [23]. More recently, ERT has been used for locating shallow cavities, fractures, fissures and mapping groundwater flow [24], identification of geological structures [25], engineering and environmental surveys [26$32]$, and in agriculture [33].

\section{The Study Area}

Lagos was the capital city of Nigeria until early 1990's when the capital territory was moved to Abuja in the center of Nigeria geographical center. Lagos remains the commercial and economic centre of the nation, the most populous and most urban centre in Africa and one of the most populated cities in the world [34]. Such geographic and demographic factors have resulted in its growing population and consequently, high rate of waste generation. In addition, there are many dumpsites located in various parts of the metropolis and almost all are surrounded by residential buildings including the study site and most have not been monitored. In Lagos each person generates around $0.5 \mathrm{Kg}$ of waste per day and with a population of around eighteen million people Lagos generates close to 10,000 MTPD (million tons per day) [35].

The study dumpsite is an open dumping system which began over twenty years ago (Figure 1). Dumping at the site is indiscriminate and unsorted. Wastes types dumped on the site are mainly domestic and non-hazardous industrial wastes. Some components of these wastes including food, papers etc, oxidize thereby changing the redox potential of the water in the dump. Percolating groundwater provides a medium through which the wastes particularly organics can undergo degradation into simpler substances through biochemical reactions involving dissolution, hydrolysis, oxidation and reduction processes. The percolating liquid dissolves different compositions of waste to form a complex mixture called leachate. This leachate mainly organic carbon largely in the form of fulvic acids migrate downward and contaminate the groundwater. Thus, shallow sources of groundwater, hand-dug wells, which constitute about $85 \%$ of sources for domestic and irrigation water systems, are at high risk of contamination from the dumpsite.

The dumpsite covers an area of about 200 to 400 square meters sloping from the west to the east and it is located near the Oke-Afa canal (Figure 2). The site was initially used as an abattoir for slaughtering and marketing cattle and sheep, before it was converted to a refuse dump by the local refuse collectors. However, a portion of the land is still being used as an abattoir.

Speculative information gathered during the course of investigation suggests the possibility of converting the dumpsite to an international market in the future while winding up the refuse dumping at the site. The long term environmental effects of creating a commercial facility on the site combined with pollution of groundwater and therefore any future wells are beyond the scope of this paper. However, this study hopes to evaluate the extent of groundwater pollution.

\subsection{Geology and Hydrogeology}

The City of Lagos sits on a flat and low-lying plain with altitude generally below 17 meters on a sedimentary basin, variously described as the Eastern portion of Da- 

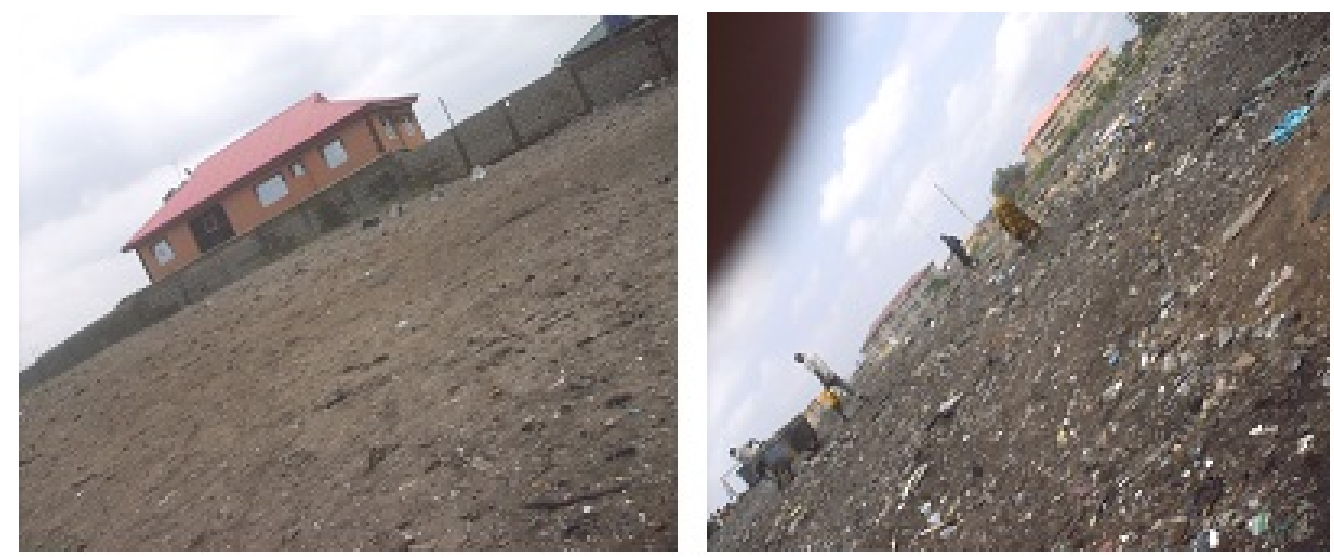

Figure 1. The dumping site as at the time of this survey.
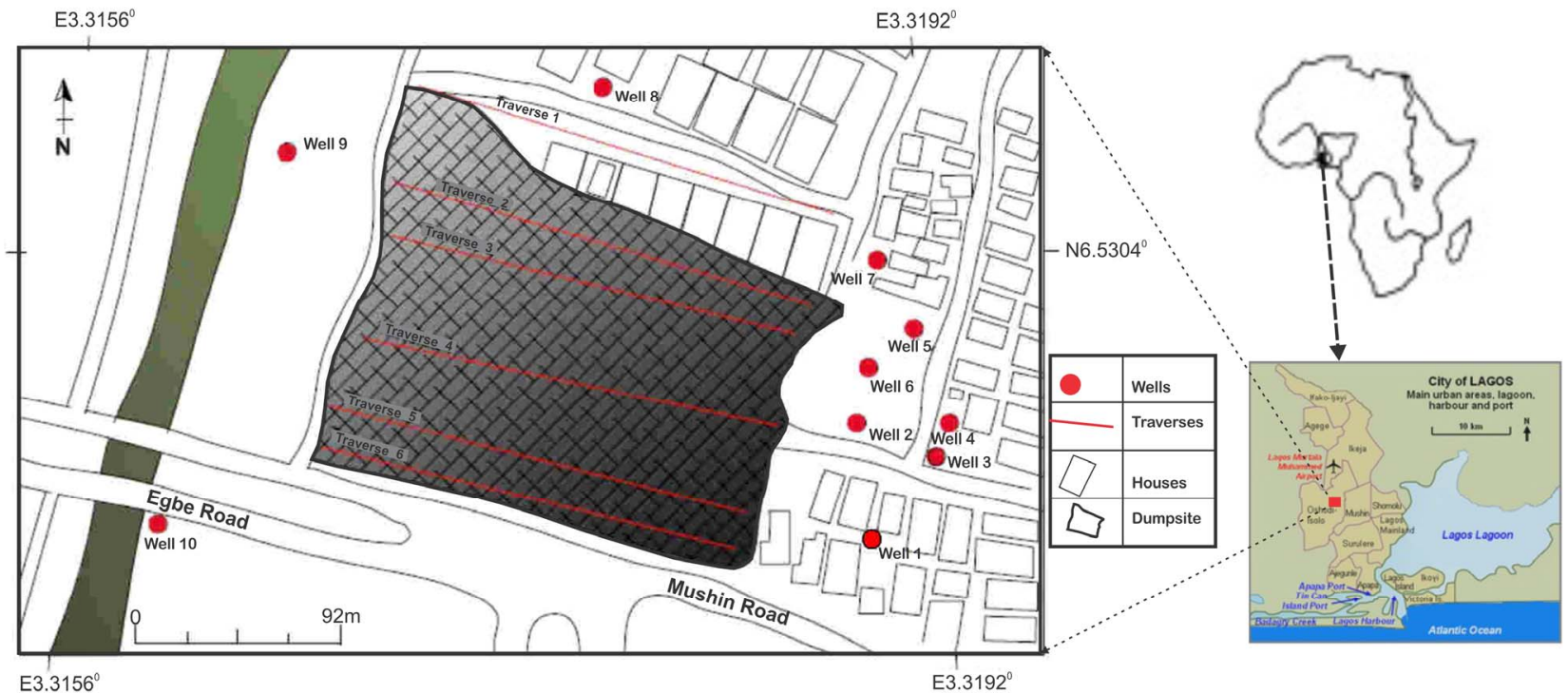

Figure 2. Data acquisition map of the study area.

homey Basin, the Nigerian sector of Benin Basin or Nigerian Southwestern basin. The basin is made up of a sequence of clays and sands, with shale and limestone intercalations [36]. Various workers have described the stratigraphy to consist of Abeokuta group (Ise, Afowo and Araromi Formations), Ewekoro, Oshosun, and Ilaro Formations and Benin formation (coastal plain sands) [36-41].

Lagos annual rainfall ranges from $2031 \mathrm{~mm}$ in the western half of the state to $2032 \mathrm{~mm}$ in the East. The Coastal Plains Sands aquifer is a multi-aquifer system consisting of three aquifer horizons separated by silty or clayey layers [42]. A shallow phreatic aquifer in present in the most recent sediment is exploited by hand-dug wells and shallow boreholes. This aquifer is (2.0 - $15.0 \mathrm{~m}$ below the surface) is prone to pollution from surficial activities. The deeper aquifers in the Ilaro Formation, $[42,43]$ are less prone to pollution. These aquifers are often confined less prone to pollution and exploited through boreholes for domestic and industrial water supply.

\section{Materials and Methods}

\subsection{Geophysical Method}

The electrical resistivity method and hydrochemical analysis of water samples from wells and boreholes were used for the investigation of possible contamination of groundwater by leachate from an open dumpsite. A total of six Electrical Resistivity Tomography (ERT) lines were surveyed covering the dumpsite (Figure 2). ERT was measured using ABEM terrameter SAS 1000, automated land imaging system with 64 electrodes. The measurement protocol is computer controlled using a laptop microcomputer together with an electronic switching unit used to automatically select the relevant four electrodes for each measurement $[44,45]$. Selection of minimum electrode spacing must be based on the target 
depth [45]. Wenner electrode configuration was chosen for its relative sensitivity to vertical changes in the subsurface resistivity below the center of the array and for its ability to resolve vertical changes (i.e. horizontal structures) [45]. Minimum electrode spacing of $3 \mathrm{~m}$ for all the profiles was maintained to attain a reading within the depth range of polluted aquifer in the area [42]. The traverses were oriented in NW-SE direction paralleled to each other and according to the geometry of the dumpsite, (Figure 2) and to ensure maximum site coverage and maximum recovery of data beneath the dumpsite. Profile one was established $70 \mathrm{~m}$ away from the dumpsite as a control while the other profiles were rightly located on the dumpsite.

Resistivity data were inverted using the Earth Imager, AGI resistivity computer program. Each commercial system (e.g. ABEM, AGI, Campus, Geofysika, Geometrics, Iris, OYO, Pasi and Scintrex) comes with its conversion program [45]. The Earth Imager computer program automatically reduce the measured resistance to apparent resistivity values, based on smoothness-constrained least-square technique of $[46,47]$, modified by [48] and applied by $[42,49,50]$. The subsurface is divided into small rectangular blocks with position and size fixed by forward modelling. The resistivity of the block is then determined so that the calculated apparent resistivity values agree with the measured values from the field survey by adjusting the resistivity of the model blocks and consequently iterate to reduce the difference between the calculated and measured (field) apparent resistivity [51]. These differences are expressed in form of RMS error. Moderate RMS errors were obtained from the survey as electrode coupling had to be improved by using water to aid conductivity.

Beside 2-D inversion of ERT data, 1-D resistivity data were extracted at notable points from each profile, processed and iterated to obtain typical 1-D resistivity model to project cross-profile geoelectrical sections for a 3-D view of the site. 1-D resistivity model samples were shown in Figure 3. We consider this necessary to reveal the subsurface condition below the depth probed with ERT, which we found useful in understanding leachate movement under the dumpsite.

In addition to resistivity data, attempts were made to measure the Induced Polarization (IP) simultaneously with the ERT data according to standard practices [52]. Measuring IP with ERT enables inversion and interpretation of the data in 2-D as previously noted by [32]. This is one of the more recent developments in the instrumentation of electrical imaging surveys [45]. The same resistivity software was employed to invert the IP data in similar process of subdividing the earth to smaller models block by forward modelling, iterating to reduce the difference between the calculated and measured apparent data; and expressing the differences in RMS error. Differences in the RMS values obtained in IP compared to ERT indicates the independence of IP data inversion from its counterpart ERT though data were acquired and recorded at the same time as well as inverted by the same computer program.

\subsection{Hydrochemical and Hydrophysical Analyses Methods}

Ten water samples were collected from water boreholes and hand-dug wells around the dumpsite-eight handdug wells at a distance range of 4 to $400 \mathrm{~m}$ from the dumpsite and two water boreholes located at a distance of 4 to $250 \mathrm{~m}$ away from the dumpsite - to determine the presence of possible contamination and the degree. Our main task is not to evaluate the impact of the contaminated water on the inhabitants of the area but to delineate and ascertain the possible linkage of the groundwater chemistry with exotic substances from the adjoining dumpsite. Our aim is achieved by juxtaposing the chemistry with threshold values which is usually WHO standard. Further details concerning health implication of excess and deficiency of these trace elements can be found in [53-57].

Samples $\mathrm{W}_{2}$ and $\mathrm{W}_{8}$ are borehole water while $\mathrm{W}_{1}, \mathrm{~W}_{3}$, to $\mathrm{W}_{7}, \mathrm{~W}_{9}$ and $\mathrm{W}_{10}$ are well water. All samples were well labeled in situ, prepared in accordance with standard practice and sent to Acme Laboratory, Canada for analysis. Anions such as $\mathrm{PO}_{4}, \mathrm{SO}_{4}, \mathrm{NO}_{3}, \mathrm{Cl}$, and 72 trace elements of including those of environmental concern were tested and analyzed for. Some in situ data collected on the water samples include conductivity (EC), total dissolved solids (TDS), $\mathrm{pH}$, temperature (T), while turbidity, total hydrocarbon content (THC) and dissolved oxygen (DO) were determined locally in the Department of Chemistry laboratory, University of Lagos. The static water levels of the hand-dug wells were also taken and found to vary between $2 \mathrm{~m}$ to $13 \mathrm{~m}$.

\section{Results, Interpretation and Discussion}

\subsection{ERT and IP Results}

The resistivity distribution derived from 2-D inversions of ERT and IP data are presented and discussed here with their resistivity-depth models (Figurs 4(a) and (b)). Generally, the subsurface below the dumpsite was characterized by low resistivity possibly influenced by contaminants emanating from the dumps. The maximum depth penetrated is $36 \mathrm{~m}$ with resisitivity values of contaminated layers below $20 \Omega \mathrm{m}$ except some few cases of high resistivity in the top layer and isolated high resistivity at depth under some profiles. The chargeability value is generally low within the impacted region $(-2.9$ $8 \mathrm{~ms}$, Figure 4(b)) which suggest possible high 

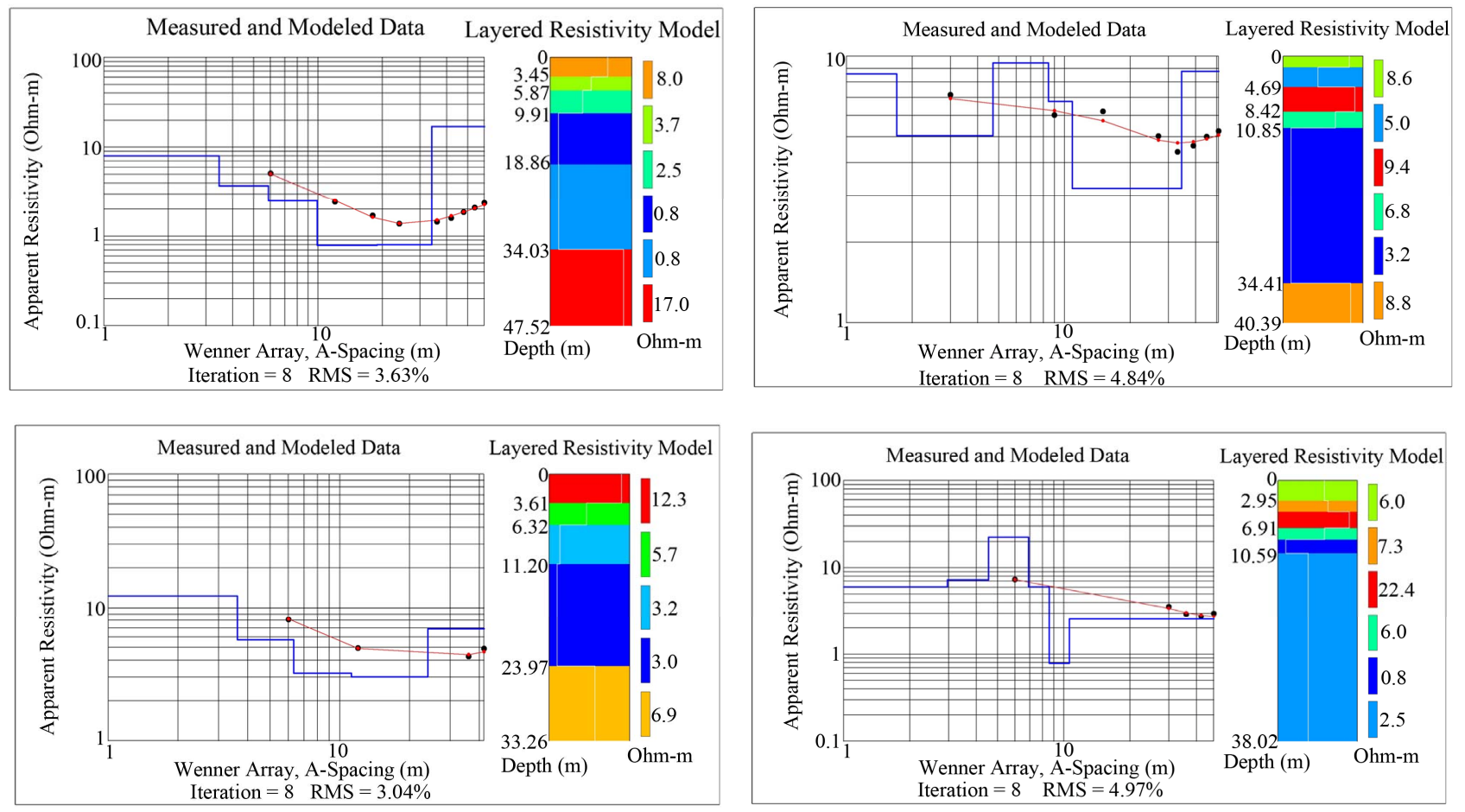

Figure 3. VES curves of extracted data from ERT.

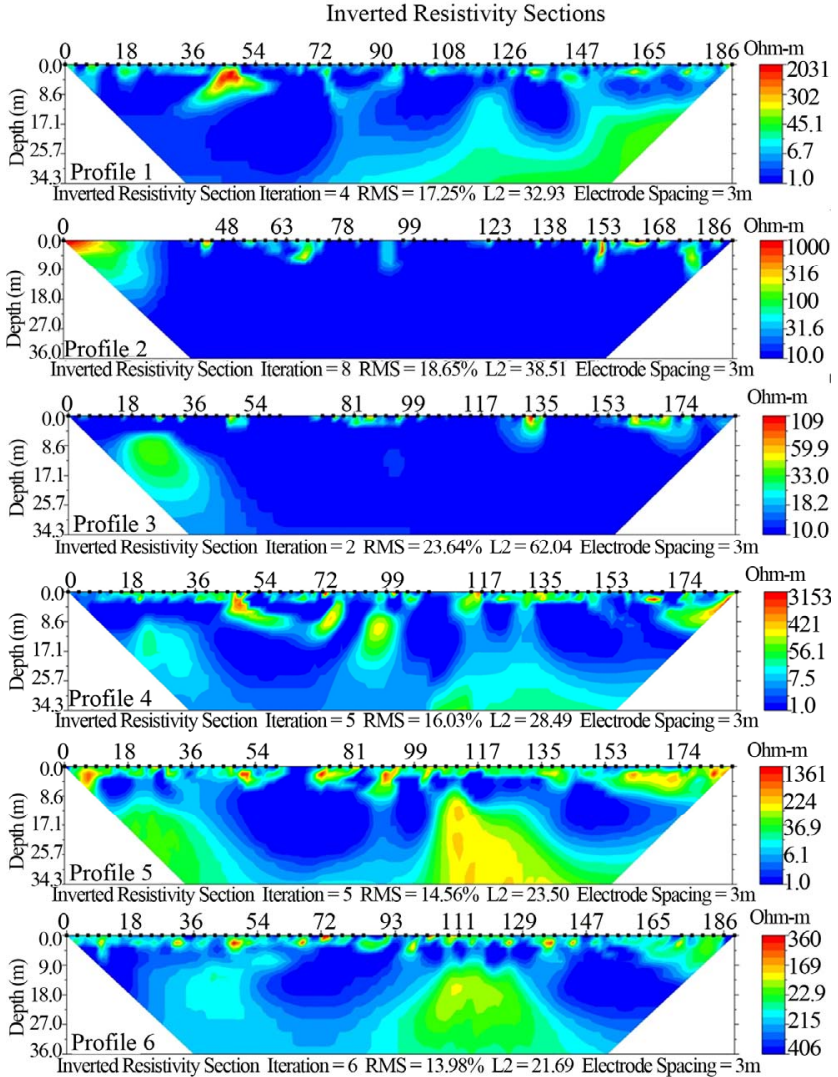

(a)

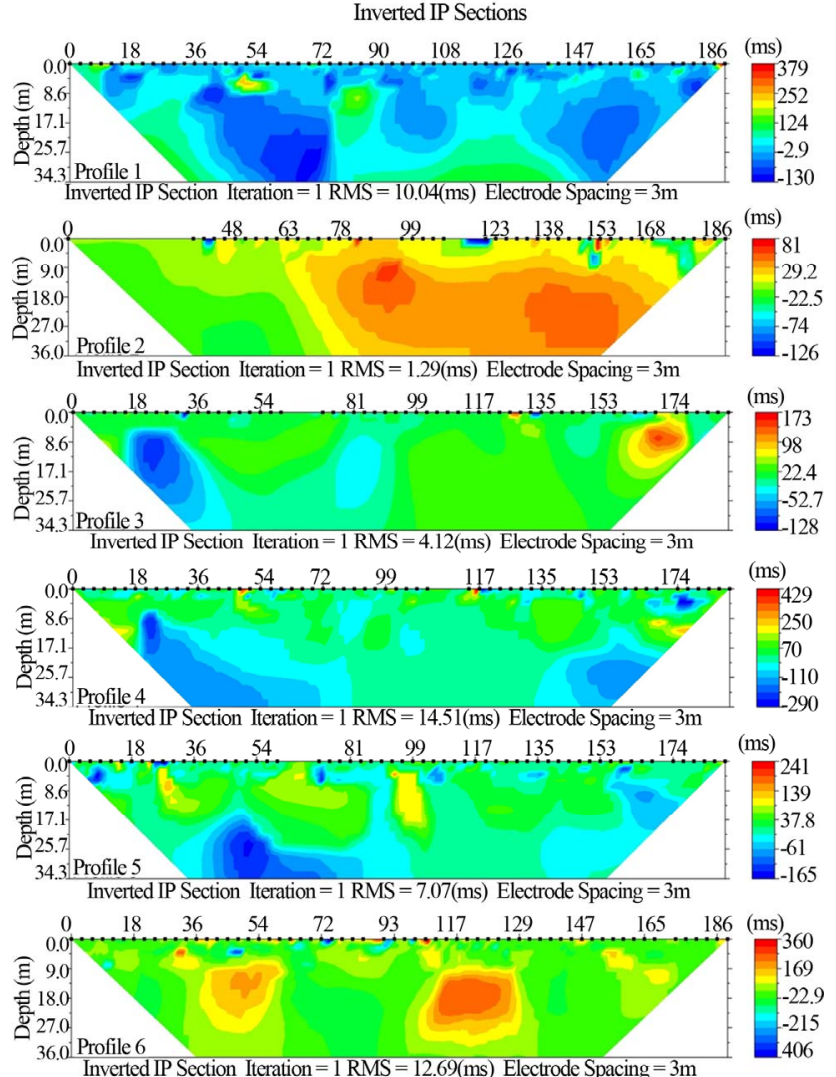

(b)

Figure 4. The dumpsite (a) ERT (b) IP tomography models for the six profiles. 
porosity and may compose of sand that has been highly impacted with leachate.

A critical look at the resistivity-depth model from ERT profile 2 to 6 shows high infiltration of leachate to the subsurface soil. From profile 2 and 3, subsurface under these profiles was characterized by resistivity between 10 and $20 \Omega \mathrm{m}$. Generally, the result reflects high level of impact of leachate from the decomposed materials from the dumpsite with resistivity $10-20 \Omega \mathrm{m}$ prevalent on the entire traverse. The depth of pollution with low resistivity values is indicative that the leachate from the decomposed refuse material has impacted the subsurface as a result polluting the groundwater particularly the first and second aquifers [42,43]. High resistivity encountered between electrode positions 18 and 36 at the depth of 4 $30 \mathrm{~m}$ under profile 3 possibly reflects the presence of a non-conductive waste since the IP measured over it has no indication of any geologic relevance compared with the IP range of geologic materials according to [52]. Similar buried exotic non-conductive materials were delineated from ERT and IP inverted section at a land reclamation site within Lagos metropolis [32]. It should also be noted that waste dumped at the site were not sorted as earlier mentioned.

Similarly, models from profiles 4 - 6 reflect resistivity from $1-20 \Omega \mathrm{m}$ for the polluted area but more pronounced in the first half of profiles 5 and 6 than in the last parts. Pockets of high resistivity from profiles 4 to 6 could possibly be attributed to non-conductive, non-decompose waste buried by other waste residues dumped after. Also, at electrode positions 105 - $135 \mathrm{~m} \mathrm{(9} \mathrm{m} \mathrm{depth}$ downward), was a suspected uncontaminated impermeable exotic material $(177-800 \Omega \mathrm{m})$ attesting to the indiscriminate dumping system and unsorted nature and varieties of the dumps being deposited at the site.

Worthy of note is the control profile (profile 1) which indicates more contamination than other profiles far from it. The possibility we think responsible for this is whether the place has been part of the dumpsite site before being cleared to pave way for buildings presently located on it. If the later being the case, it is then expected to find the wells around the area contaminated with leachate from the dumpsite, which is confirmed by geochemical analysis of the well water (Well 8).

\subsubsection{Pollution Depth Estimate}

The pollution depth was estimated by mapping out depths of pollution at intervals on the ERT traverses, based on the inverted resistivity value $(<20 \Omega \mathrm{m})$ and the GPS coordinates, to produce pollution depth estimate map (Figure 5) showing the extent of pollution. A depth range of 0 to $35 \mathrm{~m}$ was marked out as polluted cutting across the profiles. The anti-synclinal nature at the center (point of highest depth) possibly suggests the center of dumping activity and the first place dumping began many years ago. A critical view of the map also helps to decipher the possible migration path as N-S and NW-SE directions. Water moves from region of high concentration and altitude to region of low concentration and low altitude. However, groundwater, unlike surface water, has no clear paths. Migration is controlled by such factors as porosity and permeability of the media as well as concentration of pore liquid. It implies that all the permeable layers within the depth range must have been invaded by the scavenging substance (leachate). Static water level (for hand-dug wells) in the area ranges from $2 \mathrm{~m}$ to $9 \mathrm{~m}$, an indication that the first aquifer has been complete overthrown by the intruding discharge from the waste while the second aquifer is gradually being infiltrated in the same way.

\subsubsection{Extracted VES Interpretation}

An attempt was made to extract the Vertical Electrical Sounding (VES) data from the 2D data using Earth Imager Software. The data were extracted at selected locations along the traverse and inverted using 1-D inversion model of Earth Imager computer program to produce the 1-D model Curves as shown in Figure 3. From the inverted VES, we intended to view resistivity distributions across the profiles. Approximately equal surface positions on each profile are connected to make a 2-D view (geo-electric section, Figure 6) and the results discussed in traverses. The first traverse cut across profiles 2, 4-6 with top material thickness of $1.33-3.2 \mathrm{~m}$. The thickness of waste material/contaminated region varies from $10-15 \mathrm{~m}$ while the underlying sandy soil (groundwater aquifer) is not spared from the pollution effect. The second traverse extracted from surface positions 92 - $96 \mathrm{~m}$ of traverses 1 - 5 has $1.01-4.07 \mathrm{~m}$ thick top materials and $5.93-20.24 \mathrm{~m}$ thickness of waste/ contaminated region. The sandy horizon here is also infiltrated by the discharge from decomposed wastes.

Combining the ERT view with the extracted VES gives a 3-D view of the subsurface under the dumpsite (Figure 6). It shows an underground soil completely invaded by discharge from the overlying decomposed refuse material to a depth above $35 \mathrm{~m}$. By interpretation, the second aquifer harnessed through boreholes, which was the basis of mini-water works in Lagos metropolis has been affected in the study site.

\subsection{Hydrochemical Analysis}

Many authors have noted that, besides the vertical infiltration of leachate from the solid waste, the hydrological groundwater flow also play a prominent role in contaminant distributions beneath the subsurface of a landfill or dumpsite, [11,58]. This accounts for the contamination of groundwater aquifer not directly or vertical 


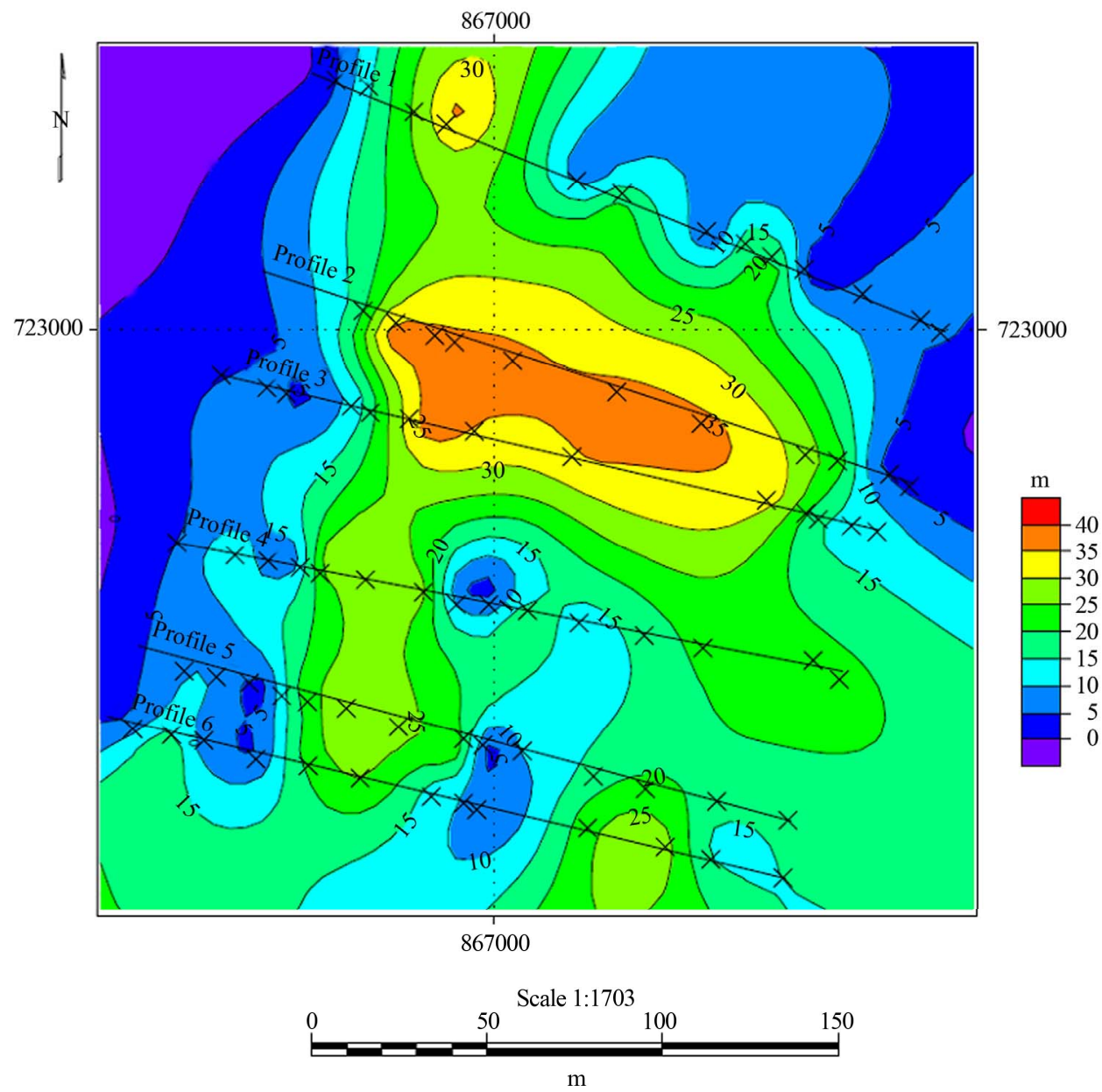

Figure 5. Pollution depth estimate map from ERT traverses from the study area. Note the anti-synclinal center (point of highest depth) possibly pointing to the center of dumping activity and the first place dumping began many years ago.

located on dumpsite or landfills across the globe. Table $\mathbf{1}$ provides the $\mathrm{pH}$ and major elemental compositions of water from wells and boreholes in the immediate surroundings of the site. Because of the persistent and indiscriminate burning coupled with heterogeneous nature of the waste, $\mathrm{pH}$ value in the acidic domain is expected since the residue after burning dissolves and percolates the subsurface making the water more acidic ( $\mathrm{pH}$ of 5.15 6.35 are predominant). Only $\mathrm{Na}$ and $\mathrm{K}$ show high values but not necessarily at toxic level. The elements are essential in humans, though may cause some health effects in susceptible individuals while elevated concentration may give rise to unacceptable taste [57]. The $\mathrm{S}$ content is high. Table 2 represents the heavy metal contents $(\mathrm{mg} / \mathrm{l})$ of the ten water samples, showing relatively elevated values for $\mathrm{Br}$.

The anion contents, electrical conductivity, and other physical parameters measured on the water samples collected from wells and boreholes in the precinct on the dumpsite are provided in Table 3. $60 \%$ of the EC measured are above the threshold value [59]. Most elevated
EC values obtained attest to the presence of electrically charged ions as reflected in the resistivity surveying earlier explained (resistivity of $20 \Omega \mathrm{m}$ is predominant). Around $50 \%$ of the water samples collected showed TH (total hardness) values greater than $200 \mathrm{mg} / \mathrm{l}$ and about $30 \%$ showed DO (dissolved oxygen) above 5 . In contrast, nitrates, sulphate and phosphate are extremely lower than the threshold values. [59] requirements for TDS in drinking water differs from WHO owing to variety in environmental, social, cultural, economic, dietary and other conditions affecting potential exposure as recognized by the world body [57]. $40 \%$ of the water showed elevated TDS values (by [59] standard), an indication of the presence of inorganic salts (principally calcium, magnesium, potassium, sodium, bicarbonates, chlorides and sulfates) [57].

In addition, we observed high correlations between EC and $\mathrm{Cu}, \mathrm{Ni}, \mathrm{pH}, \mathrm{Mg}, \mathrm{PO}_{4}, \mathrm{SO}_{4}$, TDS and $\mathrm{TH}$ and between chloride and $\mathrm{As}, \mathrm{Mg}, \mathrm{Co}, \mathrm{Ni}, \mathrm{K}, \mathrm{Na}$, and salinity (Figure 7). These physical and geochemical parameters were strongly correlated which also gives credence to 


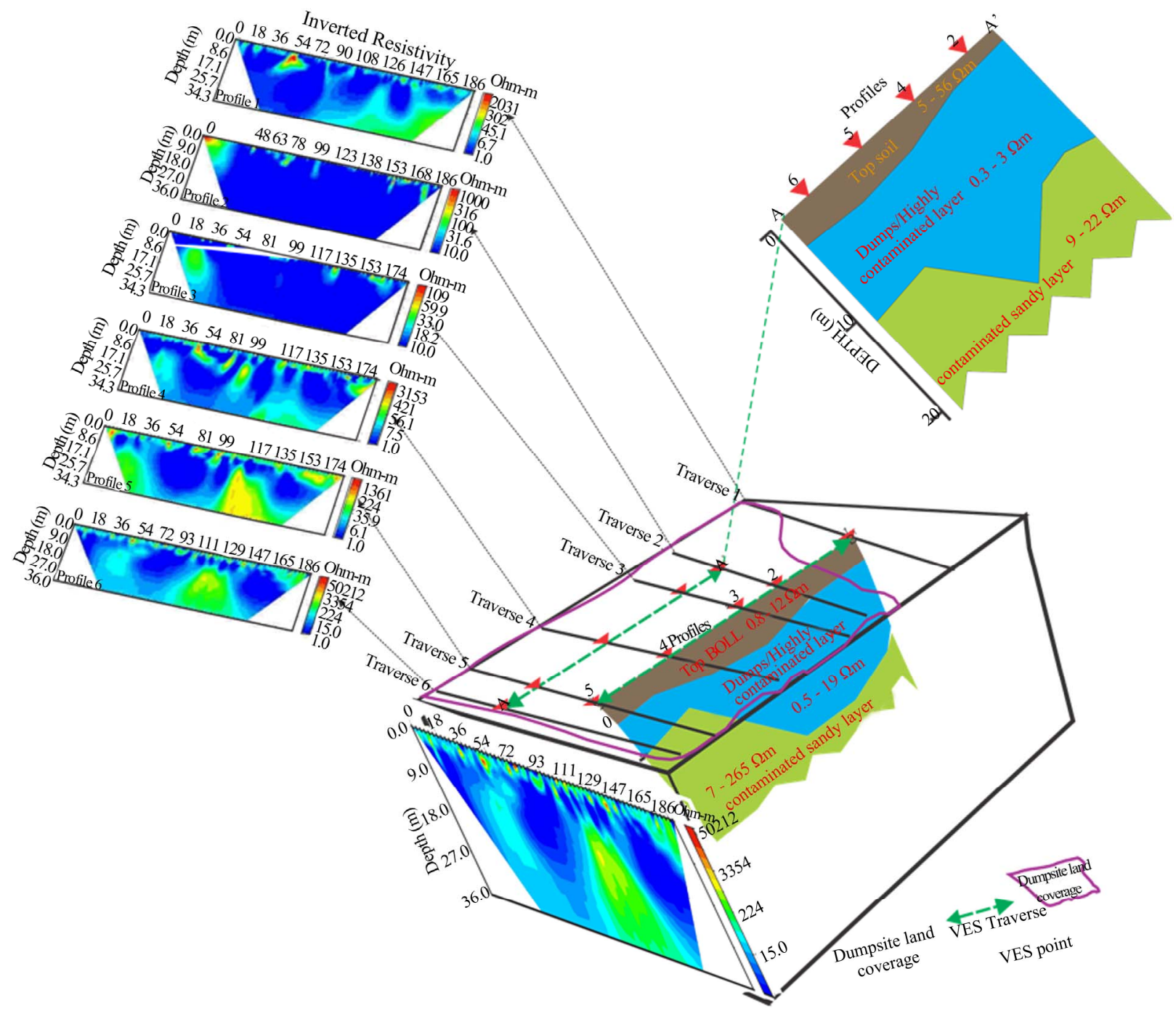

Figure 6. A 3-D block model of the dumpsite projected from ERT and cross-profile 1-D geoelectric sections.

Table 1. pH, macroelements and Boron contents (mg/l) of water samples obtained from wells and boreholes around the dumpsite.

\begin{tabular}{|c|c|c|c|c|c|c|c|c|c|}
\hline Samples & $\mathrm{pH}$ & $\mathrm{Ca}$ & $\mathrm{Mg}$ & $\mathrm{K}$ & $\mathrm{Na}$ & $\mathrm{P}$ & $\mathrm{S}$ & $\mathrm{Al}$ & B \\
\hline W1 & 6.55 & 63.05 & 11.15 & 48.66 & 54.08 & nd & 16 & 0.001 & 0.343 \\
\hline W2 & 5.15 & 36.21 & 7.01 & 26.84 & 83.74 & 0.025 & 3 & 0.025 & 0.09 \\
\hline W3 & 6.35 & 80.74 & 10.31 & 36.54 & 83.54 & nd & 10 & 0.013 & 0.177 \\
\hline W4 & 6.26 & 93.94 & 9.64 & 32.87 & 62.28 & nd & 22 & 0.01 & 0.117 \\
\hline W5 & 6.59 & 48.84 & 7.13 & 30.5 & 161.1 & nd & 12 & 1.641 & 0.02 \\
\hline W6 & 6.17 & 61.6 & 10.83 & 57.03 & 81.64 & 0.326 & 19 & 0.013 & 0.149 \\
\hline W7 & 6.26 & 39.7 & 5.7 & 24.66 & 29.7 & 0.153 & 4 & 0.089 & 0.172 \\
\hline W8 & 6.25 & 48.95 & 14.85 & 76.41 & 104.3 & nd & 47 & 0.026 & 0.061 \\
\hline W9 & 6.89 & 56.78 & 50.52 & 118.2 & 58.62 & nd & 30 & 0.007 & 1.438 \\
\hline W10 & 6.17 & 82.2 & 43.38 & 286.7 & 175.5 & 0.089 & 12 & 0.018 & 2.063 \\
\hline Mean & 6.26 & 61.2 & 17.05 & 73.84 & 89.45 & 0.148 & 17.5 & 0.1843 & 0.463 \\
\hline ST & 0.45 & 19.17 & 16.6 & 80.1 & 46.42 & 0.13 & 13.17 & 0.5124 & 0.67 \\
\hline
\end{tabular}


Table 2. Heavy metals contents $(\mu \mathrm{g} / \mathrm{l})$ of water samples obtained from wells and boreholes around the dump.

\begin{tabular}{ccccccccccccc}
\hline Samples & As & Cd & Zn & $\mathrm{Ba}$ & $\mathrm{Mn}$ & $\mathrm{Cu}$ & $\mathrm{Co}$ & $\mathrm{Cr}$ & $\mathrm{Ni}$ & $\mathrm{Pb}$ & $\mathrm{Br}$ \\
\hline W1 & nd & 0.06 & 5.4 & 29.05 & $\mathrm{nd}$ & 10.3 & 0.12 & 7.4 & 4.8 & nd & 370 \\
W2 & 0.7 & 0.28 & 7.1 & 42.46 & 0.7 & 5.1 & 0.18 & 6.7 & 1.8 & nd & 482 \\
W3 & 0.9 & 0.06 & 2 & 33.15 & 0.9 & 2.8 & 0.16 & 8.6 & 0.3 & nd & 700 \\
W4 & 0.5 & 0.1 & 9 & 38.28 & 0.5 & 4.3 & 0.12 & 9.1 & nd & nd & 278 \\
W5 & 1.4 & 0.23 & 35.4 & 203.4 & 1.4 & 4.2 & 2.18 & 0.7 & 3.8 & 2.3 & 371 \\
W6 & 1 & nd & 9.6 & 32.92 & 1 & 6 & 0.21 & 7.6 & 1.7 & nd & 266 \\
W7 & 0.8 & nd & 25.1 & 33.08 & 0.8 & 8.5 & 0.12 & 4.4 & 1.6 & 0.1 & 138 \\
W8 & 1.1 & 0.14 & 45.9 & 127.5 & 1.1 & 9.2 & 0.57 & 3.8 & 2.2 & 7 & 890 \\
W9 & 1.4 & nd & 4.3 & 76.14 & 1.4 & 19.6 & 0.43 & 13.4 & 7.3 & 0.2 & 269 \\
W10 & 4.2 & nd & 3.2 & 116.8 & 4.2 & 8.5 & 1.49 & 21.4 & 9.2 & nd & 3547 \\
Range & $0.5-4.2$ & $0.06-0.24$ & $2.0-45.9$ & $29-203.4$ & $0.5-4.2$ & $2.8-19.6$ & $0.12-2.18$ & $0.7-21.4$ & $0.3-9.2$ & $0.1-7.0$ & $138-3547$ \\
Mean & 1.33 & 0.145 & 14.7 & 73.28 & 1.33 & 7.85 & 0.56 & 8.31 & 3.63 & 2.4 & 731 \\
ST & 1.12 & 0.092 & 15.32 & 58.46 & 1.12 & 4.82 & 0.708 & 5.73 & 2.96 & 3.23 & 1014 \\
\hline
\end{tabular}

Table 3. Anions contents and physical parameters of water collected from wells and boreholes around the dumpsite.

\begin{tabular}{ccccccccccccc}
\hline & $\mathrm{Cl}$ & $\mathrm{NO}_{3}$ & $\mathrm{PO}_{4}$ & $\mathrm{SO}_{4}$ & $\mathrm{EC}$ & $\mathrm{TDS}$ & $\mathrm{Salinity}$ & $\mathrm{DO}$ & $\mathrm{TH}$ & Turb & Temp & $\mathrm{SWL}$ \\
\hline Samples & $\mu \mathrm{g} / 1$ & $\mu \mathrm{g} / 1$ & $\mu \mathrm{g} / 1$ & $\mu \mathrm{g} / 1$ & $\mu \mathrm{S} / \mathrm{cm}$ & $\mu \mathrm{g} / 1$ & $\mu \mathrm{g} / 1$ & $\mu \mathrm{g} / 1$ & $\mu \mathrm{g} / 1$ & $\mathrm{NTU}$ & $\left({ }^{\circ} \mathrm{C}\right)$ & $\mathrm{m}$ \\
$\mathrm{W} 1$ & 70 & 1.2 & 0.09 & 0.07 & 952 & 480 & 0.18 & 4.4 & 200 & 4.5 & 28.2 & 8 \\
$\mathrm{BW} 2$ & 93 & 2.3 & 0.06 & 0.09 & 454 & 211 & 0.22 & 4.2 & 140 & 2.7 & 27.9 & \\
W3 & 107 & 2.5 & 1.2 & 1.21 & 954 & 388 & 0.23 & 4.3 & 236 & 2.9 & 28.3 & 6 \\
W4 & 62 & 2.6 & 0.1 & 1.27 & 1014 & 249 & 0.09 & 4.1 & 240 & 1.5 & 28.4 & 8.6 \\
W5 & 187 & 1.9 & 0.7 & 1.01 & 1151 & 573 & 0.4 & 4.2 & 228 & 3.2 & 28.4 & 13 \\
W6 & 85 & 2.2 & 0.05 & 0.06 & 994 & 496 & 0.17 & 4 & 188 & 6.9 & 28.3 & 5 \\
W7 & 40 & 1.76 & 2.1 & 0.08 & 1007 & 504 & 0.08 & 4.3 & 120 & 2.2 & 28.2 & 6 \\
BW8 & 163 & 1.24 & 1.7 & 0.05 & 1120 & 561 & 0.34 & 4.1 & 164 & 2.9 & 29.9 & 29.9 \\
W9 & 102 & 3.5 & 3.2 & 2.09 & 1643 & 822 & 0.18 & 4 & 652 & 22.3 & 29.9 & 2 \\
W10 & 387 & 2.9 & 3 & 2.12 & 1123 & 399 & 0.69 & 4.2 & 428 & 22.5 & 27.2 & 4 \\
Range & $40-387$ & $1.2-3.5$ & $0.05-3.2$ & $0.05-2.12$ & $454-1643$ & $211-822$ & $0.08-0.69$ & $4.0-4.4$ & $120-652$ & $1.5-22.5$ & $27.2-29.9$ & $2.0-3.0$ \\
Mean & 130 & 2.21 & 1.22 & 0.81 & 1041 & 468.3 & 0.26 & 4.18 & 259.6 & 7.16 & 28.47 & 6.58 \\
ST & 101 & 0.71 & 1.23 & 0.85 & 289 & 174 & 0.18 & 0.13 & 161.9 & 8.17 & 0.83 & \\
\hline
\end{tabular}

same source origin which is probably the dumpsite effluents.

Of significant importance is the decreasing level of all measured parameters (total physical parameters, total anions, total heavy metals and total radioactive metals) from NW-SE direction (wells 8 - 10 to wells 1 - 7). Figure 8 was derived from the combine contributions of physical parameters (EC, TDS, Salinity, DO and TH,
Figure 8(a)); total anions $\left(\mathrm{Cl}, \mathrm{NO}_{3}, \mathrm{PO}_{4}\right.$ and $\mathrm{SO}_{4}$, Figure 8(b)); total heavy metals (As, $\mathrm{Cd}, \mathrm{Zn}, \mathrm{Ba}, \mathrm{Mn}, \mathrm{Cu}, \mathrm{Co}$, $\mathrm{Cr}$, Ni and $\mathrm{Br}$, Figure 8(c)); and total radioactive metals (U, Sr, Rb, Nd, Sb, Sm and V, Figure 8(d)) measured from water samples around the dumpsite.

For each group of parameters, we found the combine contributions of the measured parameters at each location using the equation. 

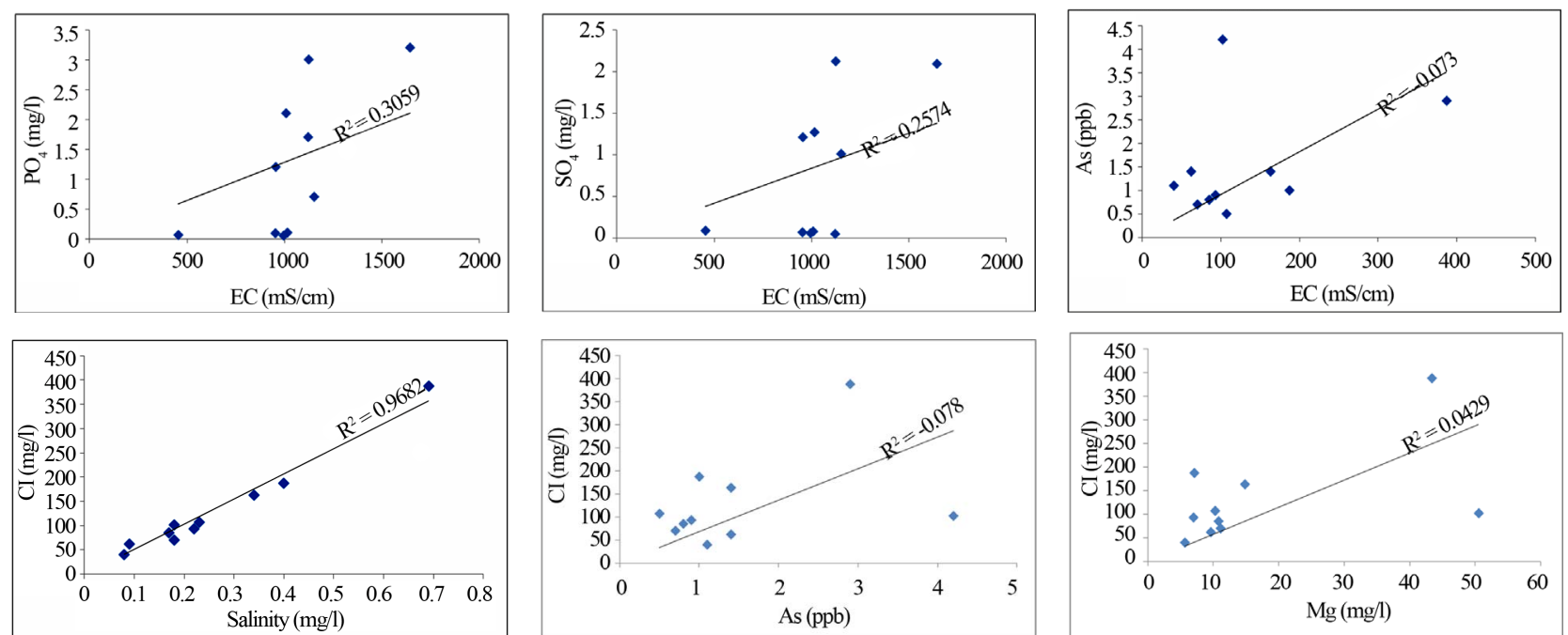

Figure 7. Scatter plots for the correlation of some measured parameters. Correlation of some of the elements, ions and physiccal parameters wth the EC and $\mathrm{Cl}$ is a direct indication of same provenance for these parameters.

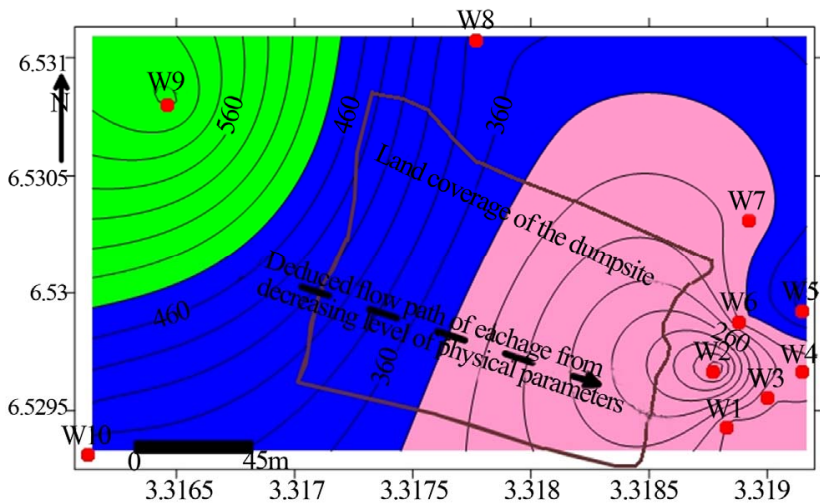

(a)

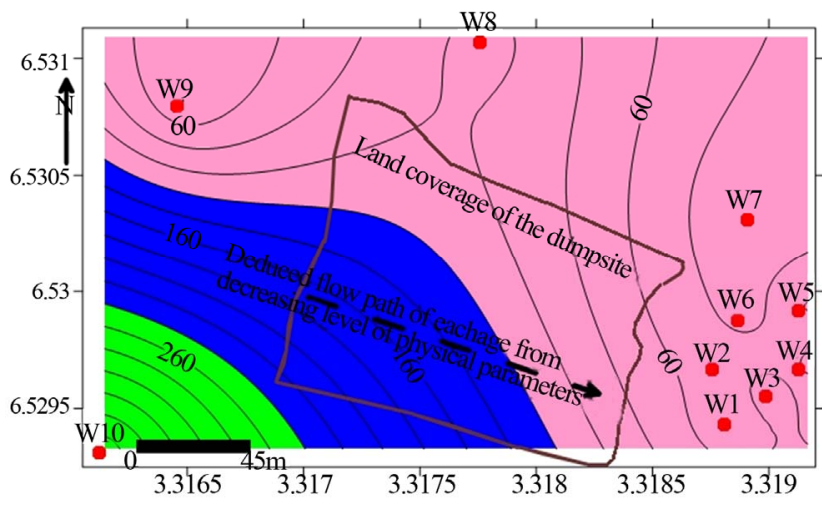

(c)

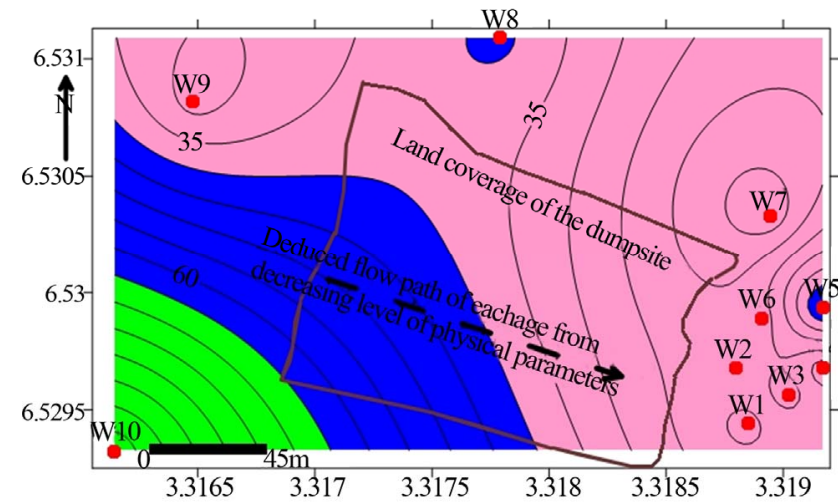

(b)

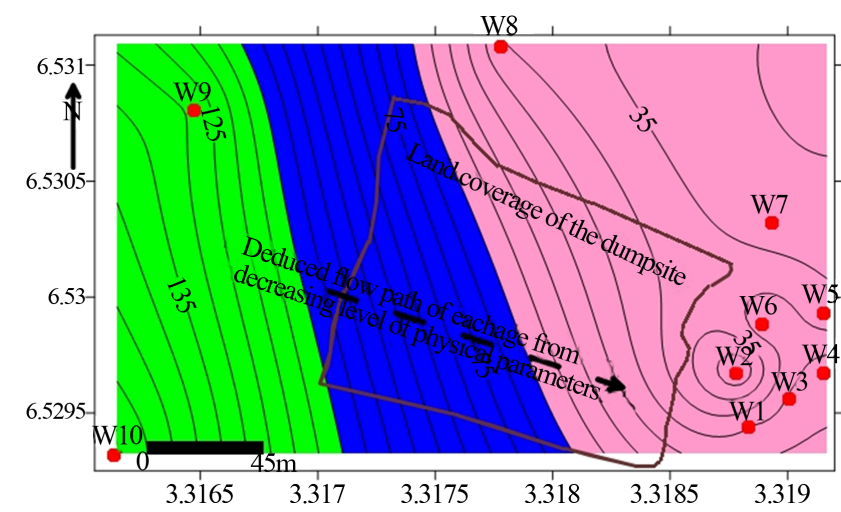

(d)

Figure 8. Leachate flow path deduced from decreasing concentrations of (a) physical parameters (b) total anions (c) total heavy metals and (d) total radioactive metals measured from water samples around the dumpsite. The parameters decrease in concentrations from the dumpsite to the surrounding groundwater, meaning that the groundwater at close proximity to the dumpsite has high concentrations of the measured physical and geochemical parameters.

$$
\sum_{1}^{n} P / n
$$

where $P=$ concentration measured parameter,
And $n=$ number of the parameters added together to make up " $P$ ". For example, for total anions,

$$
P=\mathrm{Cl}_{\text {con }}+\mathrm{NO}_{3 \mathrm{con}}+\mathrm{PO}_{4 \mathrm{con}}+\mathrm{SO}_{4 \mathrm{con}} ;
$$


Table 4. Radioactive contents $(\mu \mathrm{g} / \mathrm{l})$ water samples collected from wells and boreholes around the dumpsite.

\begin{tabular}{|c|c|c|c|c|c|c|c|}
\hline Samples & $\mathrm{U}$ & $\mathrm{Sr}$ & $\mathrm{Rb}$ & $\mathrm{Nd}$ & $\mathrm{Sb}$ & $\mathrm{Sm}$ & V \\
\hline W1 & 0.35 & 240.5 & 72.68 & nd & 0.47 & nd & 0.9 \\
\hline W2 & 0.07 & 127.8 & 41.65 & 0.08 & 0.21 & 0.02 & 0.5 \\
\hline W3 & 0.76 & 271.5 & 52.33 & 0.04 & 0.16 & nd & 0.4 \\
\hline W4 & 1.92 & 276.7 & 53.15 & 0.51 & 0.41 & 0.07 & 5.3 \\
\hline W5 & 0.36 & 167.5 & 21.05 & 52.1 & 0.16 & 9.6 & 0.9 \\
\hline W6 & 0.25 & 204.3 & 89.8 & 0.29 & 0.52 & 0.06 & 19.2 \\
\hline W7 & 0.13 & 150.6 & 54.89 & 0.31 & 1.3 & 0.06 & 17.2 \\
\hline W8 & 0.08 & 228.9 & 38.44 & 10.48 & 0.11 & 1.76 & 1.3 \\
\hline W9 & 2.6 & 640.5 & 251.4 & 0.62 & 3.26 & 0.11 & 2.4 \\
\hline W10 & 8.53 & 649.8 & 428 & 0.14 & 1.17 & 0.05 & 3.8 \\
\hline Range & $0.07-8.53$ & $127.5-649$ & $21.05-428.0$ & $0.04-52.10$ & $0.11-3.36$ & $0.02-1.76$ & $0.4-19.2$ \\
\hline Mean & 1.51 & 295.8 & 110.3 & 7.174 & 0.78 & 1.47 & 5.19 \\
\hline ST & 2.61 & 190.5 & 129.2 & 17.18 & 0.97 & 3.34 & 7.05 \\
\hline
\end{tabular}

and $n=4$ at each location.

Plotting this against the sample locations gives the combine distributions of these parameters in the area.

The parameters were observed to decrease in concentrations from the dumpsite to the surrounding groundwater, meaning that the groundwater at close proximity to the dumpsite has high concentrations of the measured physical and geochemical parameters more than those far from the dumpsite. It shows underground resultant flow path of the leachate and possibly of the groundwater as envisaged from ERT survey.

In this study, we include radioactive elements detected in the water samples as some existed in concentrations (Table 4) above other geochemical elements widely reported in most dumpsite studies (example: [11]). Sr and $\mathrm{Rb}$ are especially high. while we could not adduce any reason to the presence of these radioactive metals in the water samples, it is however suspected that some could arise from various unidentified waste usually dumped on the site, ranging from plastic to vegetation, electronics, waste cooked food, corroded metals, and other metallic and household materials.

\section{Conclusion}

Integration of electrical and geochemical methods has been used to assess the subsurface conditions under a municipal dumpsite system in Lagos. Our geophysical method was able to map and delineate the contaminant plume (leachate) beneath the aged open dumping system being recently cleared in preparation for its possible conversion into shopping complex. The integrated methods have proven to be tools for environmental assessment of waste site. The ERT and VES indicate a polluted depth of over $35 \mathrm{~m}$ beneath the surface which coincide with the upper section of the second aquifer in the area, an indication of a complete submerge of the first groundwater aquifer harness by majority through shallow wells. In the same vein, statistical analyses of geochemical and physical parameters determined in situ on groundwater from wells and boreholes located in the precinct of this site also agree to the contamination status of the site, having elevated concentrations of some macro-elements and heavy metals. The parameters also show high correlation to as a proof of same provenance. The $\mathrm{pH}$ obtained from water samples indicates high acidic content $(5.15-6.87$ $\mu \mathrm{g} / \mathrm{l})$ while about $60 \%$ of the water show high EC. Concentrations of all geochemical elements measured follow a NW-SE decreasing trend suggesting the possible flow of the leachate and consequently of the groundwater, which also agrees with similar flow pattern deduced from ERT results.

\section{REFERENCES}

[1] W. E. Kelly and M. Stanislav, "Applied Geophysics in Hyrogeological and Engineering Practice," Elsevier, Amesterdam, 1993.

[2] D. S. McFarlane, J. A. Cherry, R. W. Gilham and E. A. Sudicky, "Migration of Contaminants in Groundwater at a Landfill: A Case Study," Journal of Hydrology, Vol. 63, No. 1-2, 1983, pp. 1-29. doi:10.1016/0022-1694(83)90221-4

[3] D. Fatta, A. Papadopoulos and M. Loizidou, "A Study on 
the Landfill Leachate and Its Impact on the Groundwater Quality of the Greater Area," Environmental Geochemistry and Health, Vol. 21, No. 2, 1999, pp. 175-190. doi:10.1023/A:1006613530137

[4] S. Mor, K. Ravindra, P. R. Dahiya and A. Chandra, "Leachate Characterization and Assessment of Groundwater Pollution near Municipal Solid Waste Landfill Site," Environmental Monitoring and Assessment, Vol. 118, No. 1-3, 2006, pp. 435-456. doi:10.1007/s10661-006-1505-7

[5] E. Dimitriou, I. Karaouzas, K. Saratakos, I. Zacharias, K. Bogdanos and A. Diapoulis, "Groundwater Risk Assessment at a Heavily Industrialized Catchment and the Associated Impacts on a Peri-Urban Wetland," Journal of Environmental Management, Vol. 88, No. 3, 2008, pp. 526538. doi:10.1016/j.jenvman.2007.03.019

[6] R. K. Singh, M. Datta and A. K. Nema, "Review of Groundwater Contamination Hazard Rating Systems for Old Landfills," Waste Management \& Research, Vol. 28, No. 2, 2009, pp. 97-108.

[7] E. A. Ayolabi, A. F. Folorunso, L. Adeoti, S. Matthew and E. Atakpo, "2-D and 3-D Electrical Resistivity Tomography and Its Implications," The 4th Annual Research Conference and Fair held at the University of Lagos, Akoka, 8 Jannuary 2009, p. 189.

[8] E. A. Ayolabi, "Geoelectric Evaluation of Olushosun Landfill Site Southwest, Nigeria and Its Implications on Groundwater," Journal of the Geological Society of India, Vol. 66, No. 3, 2005, pp. 318-322.

[9] E. A. Ayolabi and J. Oyelayo, "Geophysical and Hydrochemical Assessment of Groundwater Pollution Due to a Dumpsite in Lagos, Nigeria," Journal of the Geological Society of India, Vol. 66, No. 5, 2005, pp. 617-622.

[10] E. A. Ayolabi and D. Y. Peters, "Hydrochemical and Electrical Resistivity Assessment of the Impact of Solid Waste on the Groundwater at Oke-Alfa Refuse Dumpsite," Journal of Engineering and Technology Management, Vol. 12, No. 1, 2004, pp. 5936-5946.

[11] J. Pastor and A. J. Hernández, "Heavy Metals, Salts and Organic Residues in Old Solid Urban Waste Landfills and Surface Waters in Their Discharge Areas: Determinants for Restoring Their Impact," Journal of Environmental Management, Vol. 98, 2012, pp. S42-S49. doi:10.1016/i.jenvman.2011.06.048

[12] P. C. Ogbonna and E. O. Ukiwe, "Metals (Hg, As, Fe, Cr) Uptake in Selected Woody Species in Umuahia, Nigeria," Journal of Applied Sciences in Environmental Sanitation, Vol. 6, No. 1, 2011, pp. 23-28.

[13] E. G. Akpokodje, "Principle of Applied and Environmental Geology," Paragraphic Publisher, Port Harcourt, 1999.

[14] A. A. Odewande, "Hydro-Chemical Characteristic of the Environmental Impact of Solid Waste; Dumpsite, Orita Aperin Central Refuge Dumpsite in Ibadan. South Western, Nigeria," Ph.D. Thesis, University of Ibadan, Ibadan, 1999.

[15] G. J. Udom and E. O. Esu, "A Preliminary Assessment of the Impact of Solid Wastes on Soil and Groundwater SysTem in Part of Port Harcourt City and Its Environs. Rivers State Nigeria," Global Journal of Environmental Sciences, Vol. 4, No. 1, 2005, pp. 23-30.
[16] S. Anon, "Hydrogeological Implications in Solid Waste Disposal," Bull. International Association Hydrogeol, 2009, pp. 146-158.

[17] N. Okoronkwo, J. C. Igwe and E. C. Onwuchekwa, "Risk and Health Implications of Polluted Soils for Crop Production," African Journal of Biotechnology, Vol. 4, No. 13, 2005, pp. 1521-1524.

[18] C. Bairds, "Environmental Chemistry," W.H. Free-man and Company, New York, 1995, pp. 384-387.

[19] N. J. Bunce, "Environmental Chemistry," Winers Publishing Ltd., Winnipeg, 1990.

[20] W. D. Daily, W. Lin and T. Buscheck, "Hydrological Properties of Topopah Spring Tuff: Laboratory Measurements," Journal of Geophysical Research, Vol. 92, No. B8, 1987, pp. 7854-7864. doi:10.1029/JB092iB08p07854

[21] A. Ramirez, W. Daily, A. Binley, D. LaBrecque and D. Roelant, "Detection of Leaks in Underground Storage Tanks Using Electrical Resistance Methods" Journal of Environmental \& Engineering Geophysics, Vol. 1, No. 3, 1996, pp. 189-203. doi:10.4133/JEEG1.3.189

[22] D. J. LaBrecque, A. Ramirez, W. Daily and A. Binley, "ERT Monitoring of Environmental Remediation Processes," Measurement Science and Technology, Vol. 7, No. 3, 1996, pp. 375-383. doi:10.1088/0957-0233/7/3/019

[23] W. D. Daily, A. L. Ramirez and R. Johnson, "Electrical Impedance Tomography of a Perchloroethylene Release," Journal of Environmental \& Engineering Geophysics, Vol. 2, No. 3, 1998, pp. 189-201.

[24] E. Auken, L. Pellerin, N. B. Christensen and K. Sorensen, "A Survey of Current Trends in Near-Surface Electrical and Electromagnetic Methods," Geophysics, Vol. 71, No. 5, 2006, pp. G249-G260.

[25] E. A. Al-Sayed and G. El-Qady, "Evaluation of Sea Water Intrusion Using the Electrical Resistivity and Transient Electromagnetic Survey: Case Study at Fan of Wadi Feiran, Sinai, Egypt," EGM International Workshop Innovation in EM, Gravity and Magnetic Methods: A New Perspective for Exploration Capri, Capri, 15-18 April 2007.

[26] L. Pellerin, "Applications of Electrical and Electromagnetic Methods for Environmental and Geotechnical Investigations," Surveys in Geophysics, Vol. 23, No. 2-3, 2002, pp. 101-132. doi:10.1023/A:1015044200567

[27] M. O. Olorunfemi, A. I. Idoringie and A. T. Coker, “Application of the Electrical Resistivity Method in Foundation Failure Investigation: A Case Study," Global Journal of Geological Sciences, Vol. 2, No. 1, 2004, pp. 139-151.

[28] M. Corriols and T. Dahlin, "Geophysical Characterization of the Leon-Chinandega Aquifer Nicaragua," Hydrogeology Journal, Vol. 16, No. 2, 2008, pp. 349-361.

[29] A. A. Nigm, R. A. Elterb, F. E. Nasr and H. M. Thobaity, "Contribution of Ground Magnetic and Resistivity Methods in Groundwater Assessment in Wadi Bany Omair. Holy Makkah Area, Saudi Arabia," Egyptian. Geophysical Society Journal, Vol. 6, No. 1, 2008, pp. 67-79.

[30] E. A. Ayolabi, E. A. Atakpo, L. Adeoti, E. C. Otobor and T. Arerin, "Groundwater Quality Assessment Using Predrilling Electrical Measurements," Journal of Environ- 
mental Hydrology, Vol. 17, 2009, pp. 1-12.

[31] E. A. Ayolabi, A. F. Folorunso and P. W. Obende, "Integrated Assessments of Possible Effects of Hydrocarbon and Salt Water Intrusion on the Groundwater of Iganmu Area of Lagos Metropolis, Southwestern Nigeria," Earth Sciences Research Journal, Vol. 14, No. 1, 2010, pp. 100110.

[32] E. A. Ayolabi, A. F. Folorunso and M. O. Oloruntola, "Constraining Causes of Structural Failure Using Electrical Resistivity Tomography (ERT): A Case Study of Lagos, Southwestern, Nigeria," Mineral Wealth, Vol. 156, No. 4, 2010, pp. 7-18.

[33] L. Giovanni, "The Use of Geophysical Methods for 3-D Images of Total Root Volume of Soil in Urban Environments," Exploration Geophysics, Vol. 41, No. 4, 2010, pp. 268-278. doi:10.1071/EG09034

[34] N. Myers, "Population, Resources and the Environment: The Critical Challenges," UNPF-United Nation Population Fund, New York, 1991.

[35] O. Oresanya, "Integrated Waste Management in Lagos State-Shifting the Paradigm," Annual Conference of NMGS, Minna, 6-11 March 2011, pp. 1-117.

[36] H. A. Jones and R. D. Hockey, "The Geology of Part of Southwestern Nigeria," Bulletin (Geological Survey of Nigeria), Vol. 31, 1964, p. 87.

[37] C. A. Kogbe, "Geology of Nigeria," 2nd Revised Edition, Elizabethan Publishing Company, Rock View Nigeria Ltd, Jos, 1989, p. 538.

[38] M. E. Omatsola and O. S. Adegoke, "Tectonic and Cretaceous Stratigraphy of the Dahomey Basin," Journal of Geology and Mining Research, Vol. 154, No. 1, 1981, pp. 65-68.

[39] H. G. Billman, "Offshore Stratigraphy and Paleontology of Dahomey Embayment, West Africa. Nigerian," Association of Petroleum Explorationist Bulletin, Vol. 7, No. 2, 1992, pp. 121-130.

[40] M. E. Nton, "Sedimentological and Geochemical Studies of Rock units in the Eastern Dahomey Basin, South Western Nigeria," Unpubl Ph.D. thesis, University of Ibadan, Ibadan, 2001.

[41] NGSA, "The Geological Map of Nigeria," A Publication of Nigeria Geological Survey Agency, Abuja, 2004.

[42] E. O. Longe, S. Malomo and M. A. Olorunniwo, "Hydrogeology of Lagos Metropolis," Journal of African Earth Sciences, Vol. 6, No. 2, 1987, pp. 163-174.

[43] A. A. Adepelumi, B. D. Ako, T. R. Ajayi, O. Afolabi and E. J. Omotoso, "Delineation of Saltwater Intrusion into the Freshwater Aquifer of Lekki. Peninsula, Lagos, Nigeria," Environmental Geology, Vol. 56, No. 5, 2008, pp. 927-933. doi:10.1007/s00254-008-1194-3

[44] D. H. Griffiths, J. Turnbull and A. I. Olayinka, "Two-Dimensional Resistivity Mapping with a Computer-Controlled Array," First Break, Vol. 8, No. 4, 1990, pp. 121129.

[45] M. H. Loke, "Tutorial: 2-D and 3-D Electrical Imaging Surveys," 2004 Revised Edition. www.geometrics.com
[46] A. Dey and H. F. Morrison, "Resistivity Modelling for Arbitrary Shaped Two-Dimensional Structures," Geophysical Prospecting, Vol. 27, No. 1, 1979, pp. 1020-1036. doi:10.1111/j.1365-2478.1979.tb00961.x

[47] C. Degroot-Hedlin and C. Constable, “Occam's Inversion to Generate Smooth Two-Dimensional Models from Magnetotelluric Data," Geophysics, Vol. 55, No. 12, 1990, pp. 1613-1624.

[48] M. H. Loke, "The Inversion of Two-Dimensional Resistivity Data," Ph.D. thesis, University of Birmingham, Birmingham, 1994.

[49] M. H. Loke and R. D. Barker, "Rapid Least-Squares Inversion of Apparent Resistivity Pseudosections Using a Quasi-Newton Method," Geophysical Prospecting, Vol. 44, No. 1, 1996, pp. 131-152. doi:10.1111/j.1365-2478.1996.tb00142.x

[50] T. Dahlin and M. H. Loke, "Resolution of 2D Wenner Resistivity Imaging as Assessed by Numerical Modelling," Journal of Applied Geophysics, Vol. 38, No. 4, 1998, pp. 237-249. doi:10.1016/S0926-9851(97)00030-X

[51] M. H. Loke, I. Acworth and T. Dahlin, "A Comparison of Smooth and Blocky Inversion Methods in 2D Electrical Imaging Surveys," Exploration Geophysics, Vol. 34, No. 3, 2003, pp. 182-187. doi:10.1071/EG03182

[52] S. Murali and N. S. Patangay, "Principles and Application of Groundwater Geophysics," 3rd Edition, Association of Exploration Geophysicists, Hyderabad, 2006.

[53] V. O. Olanrewaju, M. O. Olorunfemi and O. Alade, "Chemical Characteristic of Groundwater from Some Parts of the Basement Complex of Central Nigeria," Journal of Mining and Geology, Vol. 33, No. 2, 1996, pp. 135-139.

[54] K. M. Ibe Sr and A. H. O. Sowa, "Hydrogeology of Part of the Oramiriukwa River Basin, Southeast of Owerri, Imo State, Nigeria," Hydrogeology Journal, Vol. 10, No. 4, 2002, pp. 509-521. doi:10.1007/s10040-002-0207-7

[55] A. E. Ofoma, D. A. Omologbe and P. Aigberua, "Physico-Chemical Quality of Groundwater in Parts of PortHarcourt City, Eastern Niger Delta Nigeria," Water Resources, Vol. 16, 2005, pp. 18-24.

[56] P. R. Ikhane A. F. Folorunso, O. L. Shonibare, A. M. Odukoya and C. O. Shomoye, "Hydrogeochemical Study, Health Implications and Interpretation of Surface Water Analysis around Rural Settlements of Itasin and OkiGbode, Southwestern, Nigeria," Research Journal of Applied Sciences, Vol. 6, No. 12, 2010, pp. 2042-2050.

[57] W. H. O., "Guidelines for Drinking Water Quality," 4th Edition, A Publication of World Health Organization, Switzerland, 2011.

[58] M. Ahel, N. Mikac, B. Cosovic, E. Prohic and V. Soukup, "The Impact of Contamination from a Municipal Solid Waste Landfill (Zagreb, Croatia) on Underlying Soil," Water Science and Technology, Vol. 37, No. 8, 1998, pp. 203-210. doi:10.1016/S0273-1223(98)00260-1

[59] SON-Standard Organization of Nigeria, "Standard for Drinking Water Quality," Nigerian Industrial Standard, Abuja, 2007. 